\title{
FARMERS' PERCEPTION ON ROLE OF COOPERATIVES INAGRICULTURE PRACTICES OF MAJOR CEREAL CROPS IN WESTERN TERAI OF NEPAL
}

\author{
H. Neupane, M. Adhikari and P.B. Rauniyar \\ Institute of Agriculture and Animal Sciences, Tribhuvan University, Nepal
}

\begin{abstract}
A survey research was carried out in Devdaha V.D.C. and Manpakadi V.D.C of Rupandehi District with the aim to investigate the impact of cooperatives on the farming methods and the socioeconomic status of the farmers. The duration of our research was from January to June 2015. The Purposive Random Sampling wasdone where 80 Household (Sample Size) were selected for our survey i.e., 40 among them were involved in Cooperative and 40 were not. A comparative analysis was done to find the differences between cooperative and non- cooperative farmers. There were differences in various socio-economic aspects like Age, Education, ethnicity, training and subsidy, mechanization, among the cooperative and non-cooperative farmers. Significant impact was found on the farming practices, marketing status and socioeconomic condition among two different groups of farmers. Farmers involved in cooperatives were observed to perform comparatively improved farming practices which were due to accessibility of Farm Inputs and subsidy. Thus it could be concluded that there was significant impact of agricultural cooperative in the farming practices making positive changes on the livelihood of the farmers involved in cooperatives.
\end{abstract}

Key words: Cereal crops, production practices, commercialization.

\section{INTRODUCTION}

Nepal is an agro based country. About $65.6 \%$ Nepalese population have been involved in the Agriculture. It contributes about $35.5 \%$ of the National GDP. Terai is considered as the bread basket of country which fulfills greater need of agricultural production. Rupandehi district of Lumbini zone is one of the terai districts which lies in Western development. The location of the district is $83^{\circ} 12^{\prime}$ $16^{\prime \prime}$ to $83^{\circ} 38^{\prime} 16^{\prime \prime}$ E latitude and $27^{\circ} 20^{\prime} 00^{\prime \prime}$ to $27^{\circ} 47^{\prime} 25^{\prime \prime} \mathrm{N}$ longitude.

A cooperative is a user-owned and user-controlled corporate business in which benefits are received in proportion to use (USDA, 2006).Uchendu (1998) noted that the original impetus for the organization of cooperatives in developing country came from agriculture, or more precisely, from the marketing of cash coops for export. Since then cooperative development has taken different forms and dimension.Agricultural cooperatives play an important role in food production and distribution (ICA,2009).

In Nepal, there are 7230 cooperatives in core agriculture production. Besides, there are many cooperatives engaged in dairy, vegetable, fruit, horticulture and herbal production. Putting together, agriculture related cooperatives as of January 2014 are 9758 which account for 33 percent of the total cooperatives (Khatiwada, 2014).

The farmers who are based on the agriculture require assured inputs for their agricultural land and consequently good technical knowledge. The adoption of the modern techniques and tools can help the farmers to reduce their cost of production as well as save their time. Most of the farmers 
are rural based and they are deprived of the resources. They have to dependent on the agro-vets and other private agricultural service center to buy inputs for their land. The Organizational model of the cooperative brings solutions for the problems of the rural farmers under one umbrella. There is the provision of the subsidy up to fifty percent for the cooperative member along with the provision of regular training and easy access of the modern techniques and the tools that could minimize the cost of production. Similarly, the amalgamation of the scientific knowledge through in the farming practices could help to increase the food production. Thus, it addresses the problem of the food insecurity. It is the grass root level approach. The Agricultural cooperative has helped to increase the participation of the women at economic decision making level. Thus, it has also helped to empower the rural women. The study therefore was done with the aim to study whether the study site was also benefitted with the services and facilities provided by the cooperatives with the objectives to:

- compare the socio-economic conditions of farmers involved in the cooperative and not involved in cooperative.

- $\quad$ evaluate and quantify the services provided from the cooperative.

- evaluate components of the farming system and their economic analysis.

\section{METHODOLOGY}

The methodology consists of selection of the study area, sampling techniques, procedure and sample size, source of information, method and technique of data collection and data analysis.

\section{Selection of the study area}

The study was conducted in the western region of inner terai of Nepal. Manpakadi and Devdaha VDCs of Rupandehi district were selected on recommendation of District Agriculture Development Office (DADO), Rupandehi District. The study aimed at finding out the difference in farming practices and socio economic analysis of two different groups of farmers representing cooperatives and non-cooperative sector. Progressive farmers of Manpakadi and the Devdaha VDC's were purposively selected for the study.

\section{Sample Size, Sampling Procedure and the selection of the respondent}

The study was conducted on the ward number 3, 4, and 6 of Devdaha VDC and ward number 3, 4, and 7 of the Manpakadi VDC. 20 cooperative farmers and 20 non-cooperative farmers from each VDC were randomly selected with total sample size 80 households.

\section{Methods of data collection}

Various sources and the techniques were used for the collection of necessary information. In this study both the primary and secondary data were collected and analyzed.Primary source of data included those obtained from both qualitative and the quantitative research techniques including observation, focus group discussion and questionnaire survey.

Secondary Source of Data were various published material like journals, research articles, Proceedings of various NGOs and INGOs, reports of the District Agriculture Development Office (DADO), District Development Committee (DDC), National Agriculture Research Council (NARC), Central Bureau of Statistics (CBS), Village Development Committee (VDC), Community 
Development Organization (CDO). The local political leaders, working agencies were also sources of the secondary information.

\section{Survey Design and data collection}

\section{Interview Schedule Design and Field Survey}

Interview Schedule was prepared to collect Primary Information from the People associated with the cooperatives as well as the farmers who are not associated with in the cooperative organization. Pre-testing of the interview schedule was done by administrating the designed interview schedule to the farmer $(10 \%)$ of adjoining area. The final interview schedule was prepared by taking due consideration of the suggestion obtained during the pretesting. The pre-tested interview schedule (questionnaire) was administered to the respondent to collect the primary data.

\section{Methods of techniques of the data analysis}

Statistical package for social sciences (SPSS) were used in the data analysis. Statistical tools such as correlation between the variable and chi-square is used. Variables like sex of the household, ethnicity, education level, occupation, occupation, family size were considered for the descriptive analysis. Simple statistics such as percentage and frequency count were used to analyze the socioeconomic data gathered from household survey. Microsoft excel was used for producing descriptive statistics in form of bar, diagram, pie-charts and tabular form.

\section{RESULTS AND DISCUSSION}

\section{Relationship between age of farmers and cooperative membership}

The study reveals that majority of the farmers (45\%) weres of age groups 40-50 year old. However, large number of farmers those involved in co-operative sectors was 30-40 years of age while in non-cooperative sector were 40-50 years of age. The data was statistically significant at 5\% (Table 1). The finding thus indicated that farmers of older age are less interested to be involved in cooperatives.

Table 1. Relationship between age of farmers and cooperative membership

\begin{tabular}{llcc}
\hline Age & Cooperative farmers & Non-cooperative farmers & Total \\
\hline $30-40$ & $24(60)$ & $5(12.5)$ & $29(36.2)$ \\
$40-50$ & $14(35)$ & $22(55)$ & $36(45.0)$ \\
$50-60$ & $2(5)$ & $13(32.5)$ & $15(18.8)$ \\
\hline Total & $40(100)$ & $40(100)$ & $80(100)$ \\
\hline
\end{tabular}

Pearson Chi-square value $=22.293 * *(\mathrm{P}$ value $=.01$ at $2 \mathrm{df})$.

Source: Field Survey, 2015Figures in parentheses indicate the percentage.

\section{Relationship between cooperatives and Gender equity}

The table 2 illustrates the gender involvement in cooperatives. The findings showed that woman as a household head from the cooperative sector is significantly higher than the women from the non-cooperative sector. Thus the study suggests that cooperatives play an important role in women empowerment, decision making, and planning and gender role in agriculture development. FAO,2012 also claims that agriculture cooperative are a keys way to achieve social inclusion and gender-equitable. 
Table 2. Relationship between cooperatives and Gender equity

\begin{tabular}{lccl}
\hline Household Head & Cooperative Farmer & Non-cooperative Farmer & Total \\
\hline Male & $27(67.5)$ & $35(87.5)$ & $62(77.5)$ \\
Female & $13(32.5)$ & $5(12.5)$ & $18(22.5)$ \\
\hline Total & $40(100)$ & $40(100)$ & $80(100)$ \\
\hline
\end{tabular}

Pearson Chi-square value $=4.588^{*}(\mathrm{P}$ value $=.05$ at $1 \mathrm{df})$.

Source: Field Survey, 2015 Figures in parentheses indicate the percentage.

\section{Ethnicity of the Respondents in relation to cooperative farming}

The table 3 shows that majority of Brahmin and Chhetri (50\%) were involved in cooperatives followed by Tharu (25\%) whereas very few of the Dalit and Madheshi community Famers (2.5\%) were involved in cooperative. This might be because of lack of awarenessregarding the importance of cooperative in farming.

Table 3. Relationship between Cooperative membership and Ethnicity

\begin{tabular}{lccc}
\hline Caste & Cooperative Farmer & Non-cooperative Farmer & Total \\
\hline Brahmin/Chhetri & $20(50.0)$ & $9(22.5)$ & $29(36.3)$ \\
Magar & $8(20.0)$ & $6(15.0)$ & $14(17.5)$ \\
Gurung & $0(0)$ & $3(7.5)$ & $3(3.8)$ \\
Tharu & $10(25.0)$ & $14(35.0)$ & $24(30.0)$ \\
Dalit & $1(2.5)$ & $4(10)$ & $5(6.3)$ \\
Madhesi & $1(2.5)$ & $4(10)$ & $5(6.3)$ \\
\hline Total & $40(100)$ & $40(100)$ & $80(100)$ \\
\hline
\end{tabular}

Pearson Chi-square value $=11.725^{*}(\mathrm{P}$ value $=.05$ at $2 \mathrm{df})$.

Source: Field Survey, 2015 Figures in parentheses indicate the percentage.

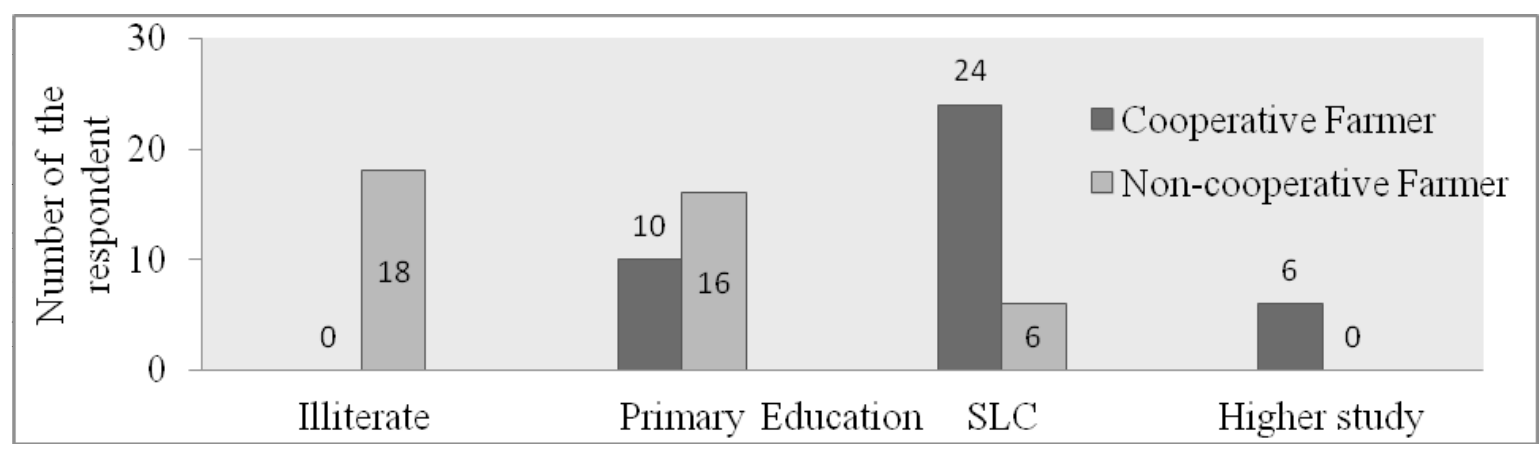

Figure 1.Role of Education in Cooperative Farming.

\section{Variety of training received by the respondents}

Higher number of farmers involved in cooperatives received training than those not involved. The table 4 below illustrates the range of trainings taken by those being involved and not involved in cooperatives. Higher percent (50\%) of those who were involved in cooperatives received wide range of trainings (offseason vegetable cultivation as well as improved cereal production) as compared to those not involved. Moreover, $80 \%$ of those who were involved in cooperatives were utilizing the learned skill which was significantly different. 
Table 4. Variety of training received by the respondents

\begin{tabular}{llll}
\hline Response & Non-Cooperative & Co-operative & Total \\
\hline No Training Received & $24(60)$ & $4(10)$ & $28(35)$ \\
Offseason vegetable cultivation & $8(20)$ & $10(25)$ & $18(22.5)$ \\
Improved cereal production & $4(10)$ & $6(15)$ & $10(12.5)$ \\
All & $4(10)$ & $20(50)$ & $24(30)$ \\
\hline Total & $40(100)$ & $40(100)$ & $80(100)$ \\
\hline
\end{tabular}

Pearson Chi-square value $=25.575^{* *}(\mathrm{P}$ value $=.01$ at $3 \mathrm{df})$.

Source: Field Survey, 2015Figures in parentheses indicate the percentage.

\section{Irrigation Practice}

The irrigation practice status of the two groups of farmers indicates that those who were involved in cooperatives were equipped with water pump and thus were able to provide adequate irrigation in rice field. Majority of the cooperative farmers $(92.5 \%)$ provided adequate irrigation in their rice field while only $55 \%$ of the non cooperative farmers had provision of adequate irrigation (Table 5). Similar result was found in wheat and maize in terms of irrigation practices.

Table 5. Irrigation Practice in Rice

\begin{tabular}{llll}
\hline Rice: Irrigation Frequency & Non-Cooperative & Co-operative & Total \\
\hline Limited Irrigation & $18(45)$ & $3(7.5)$ & $21(26.2)$ \\
Adequate Irrigation & $22(55)$ & $37(92.5)$ & $59(73.8)$ \\
\hline Total & $40(100)$ & $40(100)$ & $80(100)$ \\
\hline
\end{tabular}

Pearson Chi-square value $=14.528 * *(\mathrm{P}$ value $=.01$ at $1 \mathrm{df})$.

Source: Field Survey, 2015Figures in parentheses indicate the percentage.

\section{Weeding Practices}

The weeding practice in case of rice, wheat and maize are shown in the tables 6,7 and 8 . It was found that the frequency of mechanical weeding was higher among those not involved in cooperatives as compared to those involved whereas lower frequency of mechanical weeding was found in all three crops for those involved in cooperatives. Higher percentage of those involved in cooperatives used chemical weeding in all three crops while chemical weeding was less frequently used in these crops by those not involved. Thus there is significant difference between labour intensive farming and capital intensive farming followed by two different groups of farmers. Co-operative farmers are found to be substituting labor for chemicals which significantly reduced the cost of production as well as time spent on the farm activities.

Table 6. Weeding Practices in Rice

\begin{tabular}{llll}
\hline Rice: Method of Weeding & Non-Cooperative & Co-operative & Total \\
\hline Single Mechanical weeding & $19(47.5)$ & $0(0)$ & $19(23.8)$ \\
Twice Mechanical Weeding & $12(30)$ & $0(0)$ & $12(15)$ \\
Only Chemical Weeding & $4(10)$ & $27(67.5)$ & $31(38.8)$ \\
Both Chemical and mechanical weeding & $5(12.5)$ & $13(32.5)$ & $18(22.5)$ \\
\hline Total & $40(100)$ & $40(100)$ & $80(100)$ \\
\hline
\end{tabular}

Pearson Chi-square value $=51.620^{* *}(\mathrm{P}$ value $=.01$ at $3 \mathrm{df})$.

Source: Field Survey, 2015Figures in parentheses indicate the percentage. 
Table 7. Weeding Practices in Wheat

\begin{tabular}{llll}
\hline Wheat: Method of Weeding & Non-Cooperative & Co-operative & Total \\
\hline $\begin{array}{l}\text { No Wheat Cultivation } \\
\text { (No weeding) }\end{array}$ & $4(10)$ & $14(35)$ & $18(22.5)$ \\
Single Mechanical weeding & $22(55)$ & $4(10)$ & $26(32.5)$ \\
Only Chemical Weeding & $14(35)$ & $19(47.5)$ & $33(41.2)$ \\
Both mechanical and chemical & $0(0)$ & $3(7.5)$ & $3(3.8)$ \\
\hline Total & $40(100)$ & $40(100)$ & $80(100)$ \\
\hline
\end{tabular}

Pearson Chi-square value $=21.775^{* *}(\mathrm{P}$ value $=.01$ at $3 \mathrm{df})$.

Source: Field Survey, 2015Figures in parentheses indicate the percentage.

Table 8. Weeding Practices in Maize

\begin{tabular}{llll}
\hline Maize: Method of Weeding & Non-Cooperative & Co-operative & Total \\
\hline No weeding & $31(77.5)$ & $22(55)$ & $53(66.2)$ \\
Single Mechanical weeding & $6(15)$ & $0(0)$ & $6(7.5)$ \\
only chemical & $3(7.5)$ & $12(30)$ & $15(18.8)$ \\
Both chemical and mechanical weeding & $0(0)$ & $6(15)$ & $6(7.5)$ \\
\hline Total & $40(100)$ & $40(100)$ & $80(100)$ \\
\hline
\end{tabular}

Pearson Chi-square value $=18.928^{* *}(\mathrm{P}$ value $=.01$ at $3 \mathrm{df})$.

Source: Field Survey, 2015Figures in parentheses indicate the percentage.

\section{Manuring Practices}

The study indicates that most of the cooperative farmers follow balanced application of chemical and organic fertilizers. Most of the cooperative farmers were practicing either organic manuring $(22.5 \%)$ or both organic and chemical fertilizers (Table 9). Cooperative farmers are well acquainted that only chemical fertilizers cannot supply all essential micronutrients required by the plants so they rely on alternative sources while greater number of non-cooperative farmers are found to be relying on sole chemical fertilizers ( $35 \%$ ). Similar practices were found in wheat and maize also.

Table 9: Manure Practices in Rice

\begin{tabular}{llll}
\hline Rice: Manure Practices & Non-Cooperative & Co-operative & Total \\
\hline Only chemical fertilizer & $14(35)$ & $2(5)$ & $16(20)$ \\
Only organic manure & $2(5)$ & $9(22.5)$ & $11(13.8)$ \\
Both & $24(60)$ & $29(72.5)$ & $53(66.2)$ \\
\hline Total & $40(100)$ & $40(100)$ & $80(100)$ \\
\hline
\end{tabular}

Pearson Chi-square value $=13.926^{* *}(\mathrm{P}$ value $=.01$ at $2 \mathrm{df})$.

Source: Field Survey, 2015Figures in parentheses indicate the percentage.

\section{Legumes Incorporation}

Table 10 reveals the status of legume incorporation by two different groups of farmers. Legume incorporation is an important practice to be included in conservation of soil and sustainable 
agriculture which is performed by $70 \%$ of those involved in cooperatives while only $32.5 \%$ of those not involved in cooperative. This signifies that cooperative farmers are conscious and well acquainted with the fact that legumes incorporation will increase soil fertility and productivity substituting the chemicals input.

Table 10. Response on Legumes Incorporation by the respondents

\begin{tabular}{llll}
\hline Response & Non-Cooperative & Co-operative & Total \\
\hline No & $27(67.5)$ & $12(30)$ & $39(48.8)$ \\
Yes & $13(32.5)$ & $28(70)$ & $41(51.2)$ \\
\hline Total & $40(100)$ & $40(100)$ & $80(100)$ \\
\hline
\end{tabular}

Pearson Chi- square value $=11.257^{* *}(\mathrm{P}$ value $=0.01$ at $1 \mathrm{df})$.

Source: Field Survey, 2015 Figures in parenthesis indicate the percentage.

\section{Practice of IPM \&IPNM}

Table 11 illustrates the practices of improved agriculture. Integrated pest management and Integrated Plant Nutrient Management are two new emerging practices of Low Input Sustainable Agriculture. Cooperative farmers have received training or they have got an opportunity of tours and extension visit which is the key factor in boosting up their knowledge and skill on various innovative and improved agricultural practices in agriculture. The difference in practice of using IPM \& IPNM was highly significant as shown in table.

Table 11. Practice of IPM \&IPNM by the respondents

\begin{tabular}{llll}
\hline Response & Non-Cooperative & Co-operative & Total \\
\hline No & $30(75)$ & $13(32.5)$ & $43(53.8)$ \\
Yes & $10(25)$ & $27(67.5)$ & $37(46.2)$ \\
\hline Total & $40(100)$ & $40(100)$ & $80(100)$ \\
\hline
\end{tabular}

Pearson Chi- square value $=14.532 *(\mathrm{P}$ value $=0.01$ at $1 \mathrm{df})$

Source: Field Survey, 2015 Figures in parenthesis indicate the percentage.

\section{Method of Sowing}

\section{Method of Sowing in Wheat}

Table 12 shows the status of zero tillage practice in wheat. Zero tillage is Low cost technology for wheat cultivation. This technology is limited to research stations some Non-Government Projects for trial and few commercial farmers. The cooperative considered for study is one of the model cooperative of Nepal equipped with all the technology such as Zero tillage machines, combined harvester, Ripper, Thresher, Seed grading machines and all the modern technology. This ensures the accessibility of zero tillage machines and other modern technology for cooperative farmers. Cooperative farmers are attracted towards this technology as it reduces the cost of production on the one hand with proportionate increment on yield and income and also improve soil health. The effect was significant. This difference clears about the accessibility, affordability and awareness of cooperative farmers about the various technologies of wheat production. FAO, 2012 has also identified cooperative as a very powerful vehicle for modernizing agriculture sector which helps to generate benefits by giving farmers a voice in key decision-making 
Table 12. Method of Sowing in Wheat

\begin{tabular}{llll}
\hline Wheat: Method of Sowing & Non-Cooperative & Co-operative & Total \\
\hline No Cultivation of Wheat & $4(10)$ & $14(35)$ & $18(22.5)$ \\
Conventional tillage & $28(70)$ & $6(15)$ & $34(42.5)$ \\
Zero tillage & $8(20)$ & $20(50)$ & $28(35)$ \\
\hline Total & $40(100)$ & $40(100)$ & $80(100)$ \\
\hline
\end{tabular}

Pearson Chi- square value $=24.934 * *(P$ value $=0.01$ at $2 \mathrm{df})$.

Source: Field Survey, 2015 Figures in parenthesis indicate the percentage.

\section{Method of Sowing in Maize}

Table 13 shows the cultivation practice in maize. Maize is cultivated as cash crop by the cooperative farmers as there is high demand of green maize in the market. Non- cooperative farmers were cultivating maize for subsistence level either for home consumption or for animal feed and fodder purpose. Line sowing is of utmost essence for hybrid green maize production. Maize is competing with wheat in land and resources. There are nearly same numbers of Cooperative farmers cultivating wheat $(55 \%)$ and maize (45 \%) and majority of them were found to be practicing line sowing (30\%). Only $20 \%$ of the non- cooperative farmers cultivate maize among them only $5 \%$ perform line sowing for green maize production remaining $15 \%$ cultivate maize for fodder and feed purpose by broadcasting in subsistence level.

Table 13. Method of Sowing in Maize

\begin{tabular}{llll}
\hline Maize: Method of Sowing & Non-Cooperative & Co-operative & Total \\
\hline No cultivation of Maize & $32(80)$ & $22(55)$ & $54(67)$ \\
Broadcasting & $6(15)$ & $6(15)$ & $12(15)$ \\
Line Sowing & $2(5)$ & $12(30)$ & $14(17.5)$ \\
\hline Total & $40(100)$ & $40(100)$ & $80(100)$ \\
\hline
\end{tabular}

Pearson Chi- square value $=8.955^{* *}(\mathrm{P}$ value $=0.01$ at $2 \mathrm{df})$.

Source: Field Survey, 2015 Figures in parenthesis indicate the percentage.

\section{Purpose of Farming}

Significant difference was observed in the purpose of farming among those involved in cooperatives and not involved in cooperatives. Seventy percent of those who were not involved in cooperatives produced for the purpose of home consumption whereas only 3\% on those who were involved in cooperatives fall under this category. Among the respondents $42.5 \%$ of those involved and $30 \%$ of those not involved were producing for the dual purpose of home consumption as well as commercial purpose. Commercial seed production was practiced by $45 \%$ of the cooperative farmers while none of the non cooperative farmers were commercial seed producer (Table 14).

Table 14. Purpose of Farming by the respondents

\begin{tabular}{llll}
\hline Purpose of Farming & Non-Cooperative & Co-operative & \\
\hline Commercial Food Production & $0(0)$ & $2(5)$ & $2(2.5)$ \\
Home Consumption & $28(70)$ & $3(7.5)$ & $31(38.8)$ \\
Both & $12(30)$ & $17(42.5)$ & $29(36.3)$ \\
Commercial Seed Production & $0(0)$ & $18(45)$ & $18(22.50$ \\
\hline Total & $40(100)$ & $40(100)$ & $80(100)$ \\
\hline
\end{tabular}

Pearson Chi- square value $=41.023 * *(\mathrm{P}$ value $=0.01$ at $3 \mathrm{df})$.

Source: Field Survey, 2015 Figures in parenthesis indicate the percentage. 


\section{Production Percentage Sold}

Table 15 reveals the status of commercialization in agriculture. The percentage of product sold by cooperative and non-cooperative farmers was found to be significantly different. Sixty percent of non-cooperative farmers did not sell any of the products and $40 \%$ of them sold less than $25 \%$ of their product whereas the scenario was found to be very different among the cooperative farmers. Fifty five percent of this group sold $25-50 \%$ of their product and $45 \%$ sold more than $50 \%$ of their product. This clearly signifies the impact of being involved in the consciousness about commercialization of farming system.Zarafshani, et.al 2010 also explains that cooperative help farmers to form group and possible to get them involved in marketing of their produce.

Table 15. Production Percentage Sold

\begin{tabular}{llll}
\hline Production Percentage Sold & Non-Cooperative & Co-operative & \\
\hline Don't Sell & $24(60)$ & $0(0)$ & $24(30)$ \\
$<25 \%$ sell & $16(40)$ & $0(0)$ & $16(20)$ \\
$25-50 \%$ sell & $0(0)$ & $22(55)$ & $22(27.5)$ \\
$>50 \%$ sell & $0(0)$ & $18(45)$ & $18(22.5)$ \\
\hline Total & $40(100)$ & $40(100)$ & $80(100)$ \\
\hline
\end{tabular}

Pearson Chi- square value $=80.000 * *(\mathrm{P}$ value $=0.01$ at $3 \mathrm{df})$.

Source: Field Survey, 2015 Figures in parenthesis indicate the percentage.

\section{Mean comparison of productivity of the major crops among the sample respondent}

Table 16 shows the mean comparison of the productivity of major crops among two different groups of farmers. There was significant difference in the productivity of rice wheat and maize among cooperative and non-cooperative farmers. The productivity seemed to be highest in rice which was $1.78 \mathrm{Qt1} /$ kattha with mean difference $0.36 \mathrm{qtl}$ followed by wheat with mean difference of 0.24 . This difference was due to risk bearing capacity and improved farming practices of the cooperative farmers. The cooperative farmers were able to introduce technology; mechanization and also used optimum resources and inputs which substantially increased Crop productivity and yield. It was observed that cooperative farmers were directed towards commercialization while non-cooperative farmers were practicing subsistence farming practices with low crop yield. Zarafshani, et.al 2010 confirm that the primary objective of forming group farming cooperatives is to increase agricultural outputs.

Table 16. Mean comparison of productivity of the major crops

\begin{tabular}{lllll}
\hline Variable & Cooperative & Non co-operative & Mean difference & T value \\
\hline Rice productivity & 1.78 & 1.42 & 0.36 & $15.50^{* *}$ \\
Wheat productivity & 1.26 & 1.02 & 0.24 & $11.96^{* *}$ \\
Green Maize productivity & 545.00 & 370.00 & 175.00 & $1.64^{*}$ \\
Legumes Productivity & 0.24 & 0.19 & 0.05 & $15.58^{* *}$ \\
\hline
\end{tabular}

Note: ** \& * indicate $1 \%$ \& 5\% level of significant respectively, Productivity (Qt1/Kattha). Source: Field Survey, 2015. 


\section{SUMMARY AND CONCLUSION}

Majority of the economically active population (30-40 age group) i.e., 60\% participated in Cooperative Farming. Age had been found statistically Significant on involvement of farmers in Cooperative. The woman as a household head from the cooperative sector is significantly higher than the women from the non-cooperative sector i.e., $32.5 \%$. Cooperatives are playing an important role in women empowerment, their involvement in decision making, planning process.

Majority of the farmer from Brahmin and Chhetri Community were involved in Cooperative farming. There was active participation of such Farmers. It has found statistically Significant on involvement of farmers in Cooperative. Significant role of education was found towards the involvement on cooperative sector. All the farmers involved in cooperatives are literate while the majority of the illiterate farmers $(45 \%)$ were not the members of cooperatives. The intensity of training received was higher in case of those involved in cooperatives (90\%) than those not involved in cooperatives. This difference was found to be highly significant. Cooperatives Provides Various Skill learning opportunity.Cooperative farmers have proper information and are well acquainted about the facilities provided by the government sector and making maximum utilization of it.Progressive farmers were found to be the members of cooperatives who could bear risk and adopt new technology and higher mechanization to sustain yield and income in comparison to non-cooperative farmers.Cooperative farmers used to apply adequate amount of chemical fertilizers and other inputs in their field while non-cooperative farmers used to apply less amount inputs than the recommended dose. Farmers in cooperatives perform comparatively improved farming Practices which is due to Accessibility of farm inputs and Subsidy substantially increasing Productivity of farm.Most of the cooperative farmers were more or less directed towards commercial agriculture while non-cooperative farmers used to cultivate for home consumption in subsistence level.

\section{ACKNOWLEDGEMENT}

The authors are thankful to the administration of Paklihawa campus for support.

\section{REFERENCES CITED}

FAO. 2012. Report of the side-event Enabling Agricultural Cooperatives: A paradigm shift for economic and social inclusion. A joint FAO and COPAC side-event held during the $39^{\text {th }}$ session of the committee on world food Security (CFS), 17 October 2012, 12:30 - 14:30, Red room, FAO Headquarters. Page 4-9.

Khatiwada Y. R. 2014. Cooperatives, Economic Democracy and Human Security: Perspectives from Nepal, Ph. D. Paper presented at 1st National Cooperative Congress, March 27, 2014, Kathmandu, Nepal. Page 2-14.

Uchendu. 1998. Fundamentals of Cooperation business enterprise, published by Rejoint Communication Ltd, Uwani Enugu.

U.S. Department of Agriculture. 2006. 55. "Farmer Cooperative Statistics." Service Report67.

ICA, Statistical Information on the coop movement, Retrived August 12, 2015. http:/www.ica.coop/ coop/statistics.html.

P. S. Amaza, P. V. Kwaghe and A. A. Amos, “An analysis of women's participation in agricultural cooperatives: a case study of Borno state of Nigeria". Retrived August 12, 2015. http://www. cababstractsplus.org/abstracts/ bstract.aspx?AcNo=20026791745

Zarafshani K,F Rostamitobar, and G. H. Hosseininia. 2010. Are agricultural cooperatives successful? A case study in West Iran. American-Eurasian Journal of Agriculture and Environmental Science, 8(4):482-486. 